технології : [навч. посібник] / І. Ф. Прокопенко, В. І. Свдокимов. - Харків : Колегіум, 2006. - 224 с. 9. Рибалко Л. С. Методолого-теоретичні засади професійно-педагогічної самореалізації майбутнього вчителя (акмеологічний аспект) : [монографія] / Л. С. Рибалко. Запоріжжя : ЗДМУ, 2007. - 443 с. 10. Селевко Г. К. Современные образовательные технологии: [учеб. пособ.] / Г. К. Селевко. - Москва : Народное образование, 1998. - 256 с. 11. Шкиль А. И. Социально-психологические механизмы конфликтного взаимодействия в условиях учебно-воспитательного коллектива : автореф. дис. на соискание ученой степени канд. психол. наук: 19.00.05 / А. И. Шкиль; КГУ им. Т. Г. Шевченко. - Киев, 1990. - 22 с.

Іванна Размолодчикова

\title{
МОТИВАЦІЯ УЧІННЯ ЯК СКЛАДНИК ПРОФЕСІЙНОГО СТАНОВЛЕННЯ МАЙБУТНЬОГО ВЧИТЕЛЯ ПОЧАТКОВИХ КЛАСІВ
}

Размолодчикова I. В. Мотивація учіння як складник професійного становлення майбутнього вчителя початкових класів.

У статті зроблено спробу проаналізувати вплив внутрішньої мотивації на формування іміджу сучасного вчителя початкових класів. Досліджується проблема поняття «імідж». Висвітлено вплив культури на формування іміджу вчителя початкових класів.

Ключові слова: внутрішня мотивація, імідж майбутнього вчителя початкових класів, педагогічна культура, культура педагогічної діяльності.

Размолодчикова И. В. Мотивация обучения как составляющая профессионального становления будущего учителя начальных классов.

В статье предпринята попытка проанализировать влияние внутренней мотивации на формирование имиджа современного педагога. Исследуется проблема понятия «имидж». Высветлено влияние культуры на формирование имиджа современного педагога.

Ключевые слова: внутренняя мотивация, имидж будущого учителя начальных классов, педагогическая культура, культура педагогической деятельности.

Razmolodchikova I. V. Motivation of training as a component of professional growth of a future primary school teacher.

In the article the impact of internal motivation on formation of the modern teacher image has been examined. The problem of the concept «image» is analyzed. The culture impact on the teacher image formation has been highlighted.

Key words: internal motivation, future primary school teacher image, pedagogical culture, culture of teacher's work.

Не викликає сумніву, що справжній професіоналізм у діяльності завжди пов'язаний 3 інтенсивною та стійкою мотиваційно-емоційною спрямованістю людини на здійснення обраного виду діяльності, на досягнення в ній унікального, може навіть неординарного результату [8, с. 5].

Основними навчальними мотивами у студентів $\epsilon$ «професійні» та «особистісного престижу» [6, с. 265], але автор зазначає, на різних курсах роль домінуючих мотивів змінюється.

В останні роки посилилося розуміння психологами і педагогами ролі позитивної 
мотивації до навчання в забезпеченні успішного оволодіння знаннями і вміннями. Виявлено, що висока позитивна мотивація може відігравати роль компенсуючого чинника у випадку недостатньо високих здібностей; однак у зворотньому напрямку цей чинник не спрацьовує ніякий високий рівень здібностей не може компенсувати відсутність навчального мотиву або низьку його вираженість, не може забезпечити значні успіхи в навчанні (А. Реан, 1990).

А. Гебос (1997) виокремлює чинники (умови), які впливають на формування у студентів позитивних мотивів до навчання:

- усвідомлення найближчих і кінцевих цілей навчання;

- усвідомлення теоретичної і практичної значущості засвоюваних знань;

- емоційна форма викладу навчального матеріалу;

- показ «перспективних ліній» у розвитку наукових понять;

- професійна спрямованість навчальної діяльності;

- добір завдань, створення проблемних ситуацій у структурі навчальної діяльності;

- наявність «пізнавального психологічного клімату» в навчальній групі [6, с. 266].

Є. Ільїн наголошує, що основними чинниками, які впливають на формування стійкої мотивації до навчальної діяльності є:

- зміст навчального матеріалу;

- організація навчальної діяльності;

- колективні форми навчальної діяльності;

- стиль педагогічної діяльності педагога.

Проблема формування іміджу є однією з актуальних у сучасній педагогічній науці. Як засвідчують дослідження вітчизняних науковців, в останні роки означена проблема досить активно розробляється щодо різних видів людської діяльності.

Теоретичні підходи розгляду феномену «імідж» знаходимо у працях античних філософів (Сократ, Платон, Аристотель), мислителів Середньовіччя (Св. Августин, Ф. Аквінський, І. Даманський), Відродження (М. Фінчіо, Піко делла Мірандола, Л. Валла) і Нового часу (Ф. Бекон, Дж. Локк, Ж. Де Лабрюйєр, I. Кант, А. Шопенгауер, Г. Гегель); прикладних дослідників політичного (В. Зазикін, О. Феофанов, Г. Почепцов, І. Бєлоусова та ін.) і педагогічного іміджу (І. Зязюн, Є. Русская, В. Шепель, Л. Мітіна, В. Черепанова, П. Петрова); зарубіжних дослідників з проблем іміджу і його оптимізації (Р. Арнхейма, П. Берд, Б. Сем, К. Боулдінг, Д. Буретін, Е. Семпсон, Дж. Ягер, Е. Гоффман, Дж. Тернер, Е. Фромм та ін.).

Теоретичні та практичні аспекти дослідження іміджу державної установи, механізми формування іміджу органів влади, основні фактори впливу на формування іміджу державної установи розкрито в роботах Т. Хомуленко, Ю. Падафет, О. Скориніної.

Memy cmammi визначаємо в доведенні, що на формування професійного іміджу сучасного педагога впливає внутрішня мотивація і загальна культура.

Мотивація займає провідне місце у структурі особистості та $є$ одним 3 основних понять, що використовується для пояснення рушійних сил поведінки і діяльності.

Наявні тлумачення поняття «мотивація» нерідко ускладнюють однозначне розуміння його змісту. Мотивація, у широкому сенсі,- це все, що викликає активність людини: потреби, інстинкти, емоції, установки тощо.

Є. Ільїн подає таке визначення: «Мотивація - процес формування мотиву» [6, с. 344].

Уперше термін «мотивація» ужив А. Шопенгауер у статті «Чотири принципи достатньої причини». Під мотивацією він пояснював процес, який стимулює і підтримує поведінкову активність на певному рівні. 
Як зазначив С. Рубінштейн, «мотивація людської поведінки - це опосередкована процесом відображення суб'єктивна детермінація поведінки людини світом».

Поняття «мотивація» визначається як сукупність причин психологічного характеру, що пояснюють поведінку людини, її початок, спрямованість і активність.

Серед умов створення позитивної мотивації навчання виокремлюють:

- відповідність навчального процесу тим цілям, які ставить перед собою студент;

- задоволення пізнавальних інтересів і потреб студентів у навчальній діяльності;

- наявність ініціюючих факторів навчання - новизни, дослідницьких i творчих елементів;

- актуалізація когнітивних, потребових, регуляційних, виконавчих функції i параметрів мотивів (види, рівні, етапи, якості, вияви);

- диференційованість типів мотивації у різних формах навчання, врахування їх взаємодії;

- розходження попередньої мотивації, яка $є$ у студента до початку навчання, і власне мотивації навчання, яка повинна регулюватися викладачем;

- посилення дії спонукальних мотивів, самоствердження і самореалізації в умовах соціального запиту (духовного, інтелектуального і професійного).

У навчанні процес мотивації $є$ безперервним, оскільки вивчення будь-якого навчального матеріалу закладає основу для викладання нового. Мотивація не повинна завершуватись під час проходження чергового відрізку навчання, вона має зберігатися i підсилюватися для подальшого навчання. Процес мотивації у навчанні має характер певного циклу, він повторюється на кожному навчальному відрізку на вищому рівні. Саме тому забезпечення викладачем кожного етапу мотиваційного циклу у навчанні має здійснюватись за допомогою спеціальних прийомів і методів. Серед основних методів і прийоми мотивації, а також стимулювання навчання можна виокремити такі, як: комунікативна атака; доведення та переконання; сугестія (навіювання); подолання перешкод; делегування; закріплення позитивного враження.

Отже, мотивація повинна розглядатися як процес спрямовуючий, регулюючий i активізуючий діяльність суб'єкта навчання. Мотивація визначає змістовну вибірковість у навчальній діяльності, впливає на вибір преференційних чинників, тому що справжні мотиви краще виявляються до ситуації вибору. Селективна функція мотивації забезпечує узгодження розумів і засобів, які необхідні для іiї підтримки. Розроблення методики вивчення потреб, інтересів, цілей, деструктивних, стимулюючих факторів як основних компонентів мотиваційної сфери суб'єкта є найважливішим складником навчання. Для підсилення у студентів мотивації навчання викладач має працювати щонайменше у трьох напрямах: задіяти якомога більшу кількість мотивів; збільшити активізацію найбільш значущих мотивів; забезпечити необхідні ситуативні фактори.

В. Климчук зазначає, що внутрішня мотивація навчальної діяльності студентів має три рівні розвитку: ситуативний, перехідний та суб'єктно-ціннісний. У процесі розвитку внутрішньої мотивації від ситуативної до суб'єктно-ціннісної, мотиваційно-ціннісна сфера студентів проходить етапи диференціації (зростання іiі складності та диференційованості, поява нових цінностей) та інтеграції (подальше зростання складності, але зниження рівня диференційованості як наслідок об’єднання цінностей у нові групи).

Можливими чинниками розвитку внутрішньої мотивації $\epsilon$ досвід внутрішньо мотивованої діяльності та сформованість груп цінностей.

О. Грибенюк зазначає, що усвідомлення значущості мотиву навчання для успішної 
навчальної діяльності призвело до формування принципу мотиваційного забезпечення навчального процесу.

У структурі побудови іміджу майбутнього вчителя початкових класів важливу роль відіграє внутрішня мотивація, яка стала предметом систематичного аналізу, починаючи 3 70-х років ХХст. та започаткована експериментальними роботами Р. Раяна, М. Чікзентміхалі, Р. де Чармса, Е. Дісі, Г. Гекгаузена.

Внутрішньо мотивованою $є$ діяльність, зумовлена внутрішнім інтересом та задоволенням від іiі виконання.

Як зазначають В. Климчук та В. Горбунова, значна кількість досліджень свідчить про позитивний вплив внутрішньої мотивації - підвищення ефективності праці, зростання успішності навчання, появу психологічного комфорту.

Для виявлення рівня сформованості внутрішньої мотивації ми використовували методики: Опитувальник «Індекс прагнень» (Т. Кассер, Р. Раян), «Опитувальник внутрішньої мотивації» (Р. Раян) [7, с. 11] та методику «Вивчення мотивів навчальної діяльності студентів» (А. Реан, В. Якунін) [6, с. 434-436].

Пропонована методика має два варіанти, ми використовували варіант № 1. Наводимо його нижче.

\section{Варіант № 1}

\section{Інструкція}

Уважно прочитайте наведені у списку мотиви навчальної діяльності. Оберіть із них п’ять найбільш значущих для вас і відмітьте їх хрестиком у відповідному рядку.

\section{Список мотивів}

1. Стати висококваліфікованим спеціалістом.

2. Отримати диплом.

3. Успішно продовжити навчання на наступних курсах.

4. Успішно навчатися, здавати іспити на «добре» і «відмінно».

5. Постійно отримувати стипендію.

6. Здобути глибокі і міцні знання.

7. Бути постійно підготовленим до занять.

8. Не запускати вивчення предметів навчального циклу.

9. Не відставати від однокурсників.

10. Забезпечити успішність майбутньої професійної діяльності.

11. Виконувати педагогічні вимоги.

12. Досягнути поваги викладачів.

13. Бути прикладом для однокурсників.

14. Домогтися схвалення батьків та оточуючих.

15. Уникнути осуду та покарання за незадовільне навчання.

16. Отримати інтелектуальну насолоду.

\section{Оброблення результатів}

Для кожного студента здійснюється якісний аналіз визначальних мотивів навчальної діяльності. По всій вибірці (групі) визначається частота вибору того чи того мотиву.

Індивідуальний протокол

Прізвище, ім'я, по-батькові курс група

Номер мотиву по списку 


\begin{tabular}{|c|c|c|c|c|c|c|c|c|c|c|c|c|c|c|c|}
\hline 1 & 2 & 3 & 4 & 5 & 6 & 7 & 8 & 9 & 10 & 11 & 12 & 13 & 14 & 15 & 16 \\
\hline & $\mathrm{X}$ & & & $\mathrm{x}$ & & $\mathrm{x}$ & & & & & $\mathrm{X}$ & & & $\mathrm{x}$ & \\
\hline
\end{tabular}

Груповий протокол

Група №

\begin{tabular}{|c|c|c|c|c|c|c|c|c|c|c|c|c|c|c|c|c|}
\hline \multirow{2}{*}{ Ф.И.О. } & \multicolumn{10}{c|}{ Номер мотиву по списку } \\
\cline { 2 - 19 } & 1 & 2 & 3 & 4 & 5 & 6 & 7 & 8 & 9 & 10 & 11 & 12 & 13 & 14 & 15 & 16 \\
\hline И-в & $\mathrm{x}$ & & & $\mathrm{x}$ & & & & & $\mathrm{x}$ & & $\mathrm{x}$ & & $\mathrm{x}$ & & & \\
\hline П-в & & & $\mathrm{x}$ & & & $\mathrm{x}$ & & $\mathrm{x}$ & & $\mathrm{x}$ & & & & & & $\mathrm{x}$ \\
\hline и т.д. & & & & & & & & & & & & & & & & \\
\hline
\end{tabular}

К-сть вибору мотиву

Ранг мотиву

(який мотив обирається частіше, а який рідше)

Чим частіше обирається той чи той мотив, тим вище його ранг, тим більше він домінує у системі мотивів.

У підготовці майбутнього вчителя початкових класів формування педагогічної культури посідає особливе місце, як зазначає І. Зязюн, «високе звання «вчитель» набуває свого справжнього сенсу лише тоді, коли воно невіддільне від поняття «культура» [5].

Поділяючи думку вищеназваних науковців, нам необхідно дати визначення поняттям «культура», «педагогічна культура», «культура педагогічної діяльності», «педагогіка культури».

Культура (лат. cultura) - сукупність матеріальних і духовних цінностей, створених людиною в процесі суспільно-історичної практики [3, с. 173].

Педагогічна культура (за О. Бондаревською) - частина загальнолюдської культури, у якій найбільш повно відбилися духовні та матеріальні цінності освіти й виховання, а також засоби творчої діяльності, необхідні для обслуговування історичного процесу зміни поколінь, соціалізації особистості, здійснення освітньо-виховних процесів.

Із багатьох визначень культури ми надали перевагу саме тому, яке має безпосереднє відношення до теми нашого дослідження: «культура- це засвоєний досвід людської діяльності, рівень розвитку творчих сил і здібностей людини, виражений у способах організації життя та діяльності людини, а також створених нею цінностях».

Саме тому нам близька креативно-діяльнісна концепція культури. У ній становлення й розвиток культури пов'язується з особистістю, ії активною творчою діяльністю, об'єктами якої є не тільки природа, суспільні відносини, але й сам суб'єкт. У контексті нашого вивчення особистості (особистості майбутнього фахівця) розвиток її культури ми пов'язуємо 3 професійним іміджем та професійно-педагогічною діяльністю, яка охоплює:

- фахову підготовку;

- науково-психологічну, педагогічну та методичну озброєність;

- уміння бути експертом під час роботи над собою; 
- високу загальну культуру;

- постійне духовне збагачення;

- знання не тільки свого фаху, а й філософії, літератури, історії, права;

- знання риторики, володіння усіма стилями мовлення;

- уміння грати, як уміють грати кращі лицедії.

Мотивація посідає провідне місце у структурі особистості та $є$ одним 3 основних понять, що використовується для пояснення рушійних сил поведінки і діяльності. В останні роки значно посилилося розуміння психологами і педагогами ролі мотивації до навчання в забезпеченні успішного оволодіння знаннями і вміннями. Вона відіграє роль компенсуючого чинника у випадку недостатньо високих здібностей та сприяє формуванню професійного іміджу майбутнього вчителя початкових класів.

\section{Література}

1. Буряк В. К. Педагогічна культура: теоретико-методологічний аспект: [монографія]/ Володимир Костянтинович Буряк.- Київ: Деміур, 2005.- 232 с. 2. Воробьев Н. Е. О педагогической культуре будущего учителя / Воробьев Н. Е., Суханцева В. К., Иванова Т. В. // Педагогика. - 1992. - № 1-2. - С. 24-26. 3. Гриньова В. М. Формування педагогічної культури майбутнього вчителя (теоретичний і методичний аспект) / Валентина Миколаївна Гриньова. - Харків : Основа, 1998. - 300 с. 4. Дьяков С. I. Психологічна культура студента в контексті індивідуальної самореалізації / С. І. Дьяков // Проблеми освіти: [наук.-метод. зб.] / НМЦ ВО МОН України. - Київ, 2005. - Вип. 45: Болонський процес в Україні. - Ч. 1. - С. 120-124. 5. Зязюн I. А. Краса педагогічної дії: [навч. посіб.] / $\quad$ І. А. Зязюн, Г. М. Сагач. - Київ : Українсько-фінський інститут менеджменту і бізнесу, 1997. - 302 с. б. Ильин Е. П. Мотивы и мотивация: [учеб. пособ.] / Е. П. Ильин. - Санкт-Петербург : Питер, 2008. - 512 с. 7. Климчук В. О. Методики дослідження внутрішньої мотивації / В. О. Климчук, В.В.Горбунова //Практична психологія та соціальна робота. - 2011. - № 2 (143). - С. 11-15. 8. Погрібна В. Л. Соціологія професіоналізму: [монграфія] / В. Л. Погрібна. - Київ : Алерта : КНТ : ЦУЛ, 2008. - 336 с. 9. Размолодчикова I. В.Імідж майбутнього вчителя як компонент культури педагогічної діяльності / І. В. Размолодчикова // Вісник Черкаського університету. Серія педагогічні науки. - Вип. 165. - 2009. - С. 111-113. 10. Соціальна робота: технологічний аспект: [навч. посіб.] / за ред. А. Й. Капської. - Київ : Центр навчальної літератури, 2004. - 352 с.

УДК $159.928-053.5$

Вікторія Сушко, Тетяна Сльчанінова

\section{ЗАБЕЗПЕЧЕННЯ РОЗВИТКУ ОСОБИСТІСНИХ ЗДІБНОСТЕЙ ОБДАРОВАНИХ І ТАЛАНОВИТИХ ДІТЕЙ В УМОВАХ СУЧАСНОЇ ШКОЛИ}

Сушко В. В., Сльчанінова Т. М. Забезпечення розвитку особистісних здібностей обдарованих і талановитих дітей в умовах сучасної школи.

У статті розглянуто основи сучасного розуміння поняття обдарованість та особливості пізнавальної й емоційно-вольової сфери дитини з певним видом обдарованості. Акцентовано на необхідності психолого-педагогічного супроводу обдарованих учнів. Підкреслено необхідність розвивальної роботи з перших років навчання. Запропоновано рекомендації для педагогів щодо заходів з розвитку творчої особистості.

Ключові слова: інтелектуальна, академічна, творча, лідерська, художньо-виконавська та психомоторна обдарованість; пізнавальна сфера; навчально-виховний процес; психолого- 